\author{
International Journal of Management Science \\ and Business Administration \\ Volume 3, Issue 4, May 2017, Pages 46-57 \\ DOI: 10.18775/ijmsba.1849-5664-5419.2014.34.1006 \\ URL: http://dx.doi.org/10.18775/ijmsba.1849-5664-5419.2014.34.1006
}

\title{
Electricity Sector Reforms in Bosnia and Herzegovina: Results and Policy Implications
}

\author{
${ }^{1}$ Nela Vlahinić Lenz, ${ }^{2}$ Vedran Prša \\ ${ }^{1}$ Faculty of Economics, University of Rijeka, Croatia \\ ${ }^{2}$ Elektroprivreda Bosne i Hercegovine, Bihać, Bosnia and Herzegovina
}

\begin{abstract}
Analysis shows that electricity sector reforms in Bosnia and Herzegovina have not been implemented as they should according to the Third Energy Package and obligations deriving from the Energy Community membership. Despite the sanctions and infringement procedures for non-transposition of the Third Energy Package that has been adopted against Bosnia and Herzegovina, its legal and regulatory framework for the electricity market is still noncompliant with the Energy Community acquis. Legal framework harmonization with the Acquis communaitaire is completely missing on the state level in Bosnia and Herzegovina while the legal compliance with the Acquis is somewhat better on entity levels. Still, they do not comply with the Third Energy Package as well and this situation strongly hinders the required structural reforms and liberalization of the electricity market. Development of electricity market in Bosnia and Herzegovina has been also influenced by regional electricity market that started by European Union's incentive. Extending the European Union internal energy market to its neighboring countries, the Energy Community aims to create a regulatory and market framework capable of securing reliable energy supply and attracting investments in the energy sector. All Contracting Parties from Southeast Europe started to implement reforms in the energy sector at a different pace, but Bosnia and Herzegovina has been marked as the worst performer. It is not wondering because Bosnia and Herzegovina is a victim of its own constitutional framework and political complexity. However, during 2016 some new developments have occurred that give some hope for this country to solve some of the obstacles for functioning national and regional electricity market.
\end{abstract}

Keywords: Bosnia and Herzegovina, Southeast Europe, Energy reforms, Regional electricity market

\section{Introduction}

Due to the high importance of energy sector in GDP and overall economic activity of Bosnia and Herzegovina, energy sector reforms and new investment in electricity generation and infrastructure capacities have become a crucial economic issue. However, reforms have not been implemented smoothly due to many reasons. The absence of political agreement on the importance of the establishment of a modern and efficient energy sector is one of the main obstacles for successful electricity market reforms. This unresolved situation is the consequence of the Dayton Peace Agreement that ended the war, but also created a complex and dysfunctional institutional structure divided along ethnic lines. This dysfunctionality is especially emphasized in the energy sector due to different institutional and regulatory framework in each entity.

The aim of the paper is to give an overview of the electricity sector in Bosnia and Herzegovina and reforms results regarding restructuring and market liberalization process and analyze barriers to the future development of energy sector. This is especially important because Bosnia and Herzegovina is an Energy Community Member State and therefore obliged to implement all the reforms according to the Third Energy Package. Our hypothesis is that Bosnia and Herzegovina is burdened with complicated and dysfunctional institutional and regulatory settings of the energy sector and because of that, the reforms cannot be fully implemented. Because of incomplete sector reforms, energy sector cannot reach its competitiveness regardless of the fact that Bosnia and Herzegovina has important available energy resources. 
The paper is organized as follows. Section 2 gives an overview of the electricity sector in Bosnia and Herzegovina regarding electricity mix, legal and institutional settings. Section 3 describes the position of Bosnia and Herzegovina within the regional context specific by analyzing the development of regional electricity market and specific electricity indicators in Southeast European countries, with special reference to regional electricity trade and electricity prices. Section 4 deals with the current status of reforms and possible policy implications. Section 4 discusses the results and contains the conclusions.

\section{Electricity sector in Bosnia and Herzegovina}

\subsection{Electricity mix}

The structure of BH electricity sector is strongly dependent on hydropower since hydropower plants in Bosnia and Herzegovina have $70 \%$ share in generation installed capacities, while the rest is in thermopower plants (coal-fired). As an important exporter of electricity, Bosnia and Herzegovina produces $50 \%$ of electricity in hydropower plants. Consequently, export of electricity is highly dependent on hydrological conditions and melting of the snow. Most thermal and hydro-power plants in Bosnia and Herzegovina, mostly built in the 1960s and 1970s, are in a very bad condition with its outdated, old technology and low maintenance level. The mix of thermal and hydro generation capacities is not equally divided between the three vertically integrated public electricity companies. Electricity Company of Republika Srpska (ERS) has almost an equal share between thermal and hydro generation capacities; Electricity Company of Bosnia and Herzegovina (EP BiH) has a higher share in thermal generation capacities $(70 \%)$, while Electricity Company of Herceg-Bosna (EP HZHB) does not have any thermal generation capacities. The position of Electricity Company of Herceg-Bosna (EP HZHB) is very different in relation to ERS and EP BiH. While EP HZHB imports $50 \%$ of its needs for electricity, EP BiH and ERS are net exporters of electricity. According to many sources, the cooperation between these three vertically integrated public electricity companies is not satisfying (Balkan Energy NEWS, 2014).

The following Figure shows the shares of three vertically integrated electricity companies in electricity generation (Figure 1).

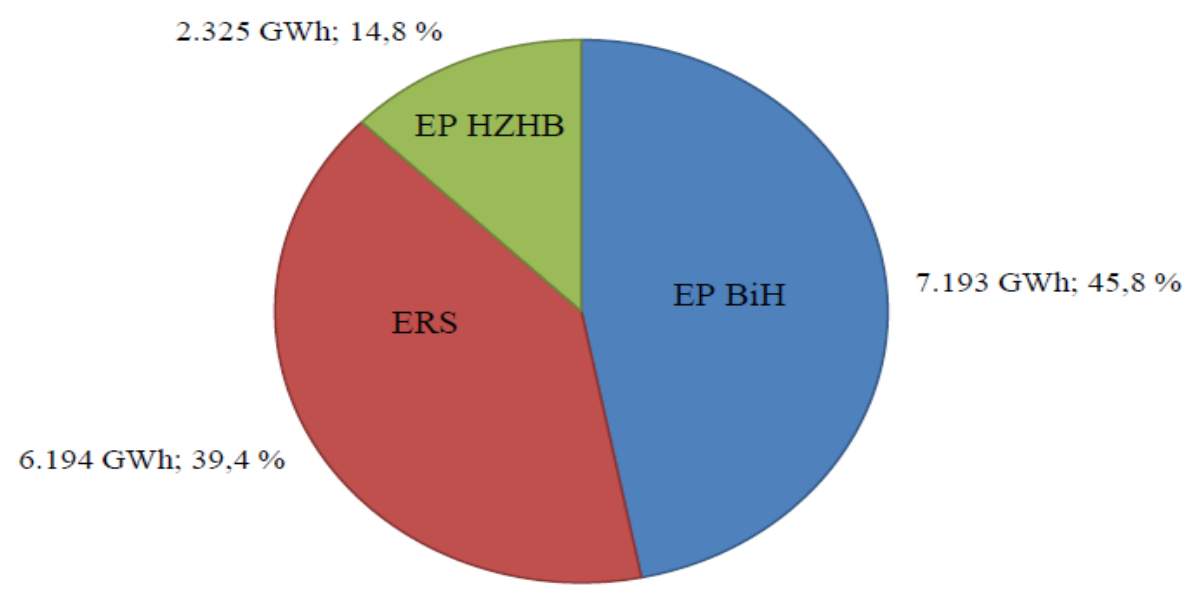

Figure 1. The share of electricity companies in Bosnia and Herzegovina in electricity generation (2015)

Source: Independent System Operator in Bosnia and Herzegovina, 2016

According to presented data, Electricity Company of Bosnia and Herzegovina has the biggest share in electricity generation (45.8\%) followed by Electricity Company of Republika Srpska (39.4\%) and Electricity Company of Herceg-Bosna (14.8\%). Two biggest companies EP BiH and ERS have sufficient generation capacities for meeting their own demand and a significant share of its electricity generation for export.

The dynamics of electricity generation structure in Bosnia and Herzegovina during past ten years is shown in the following Figure (Figure 2). 


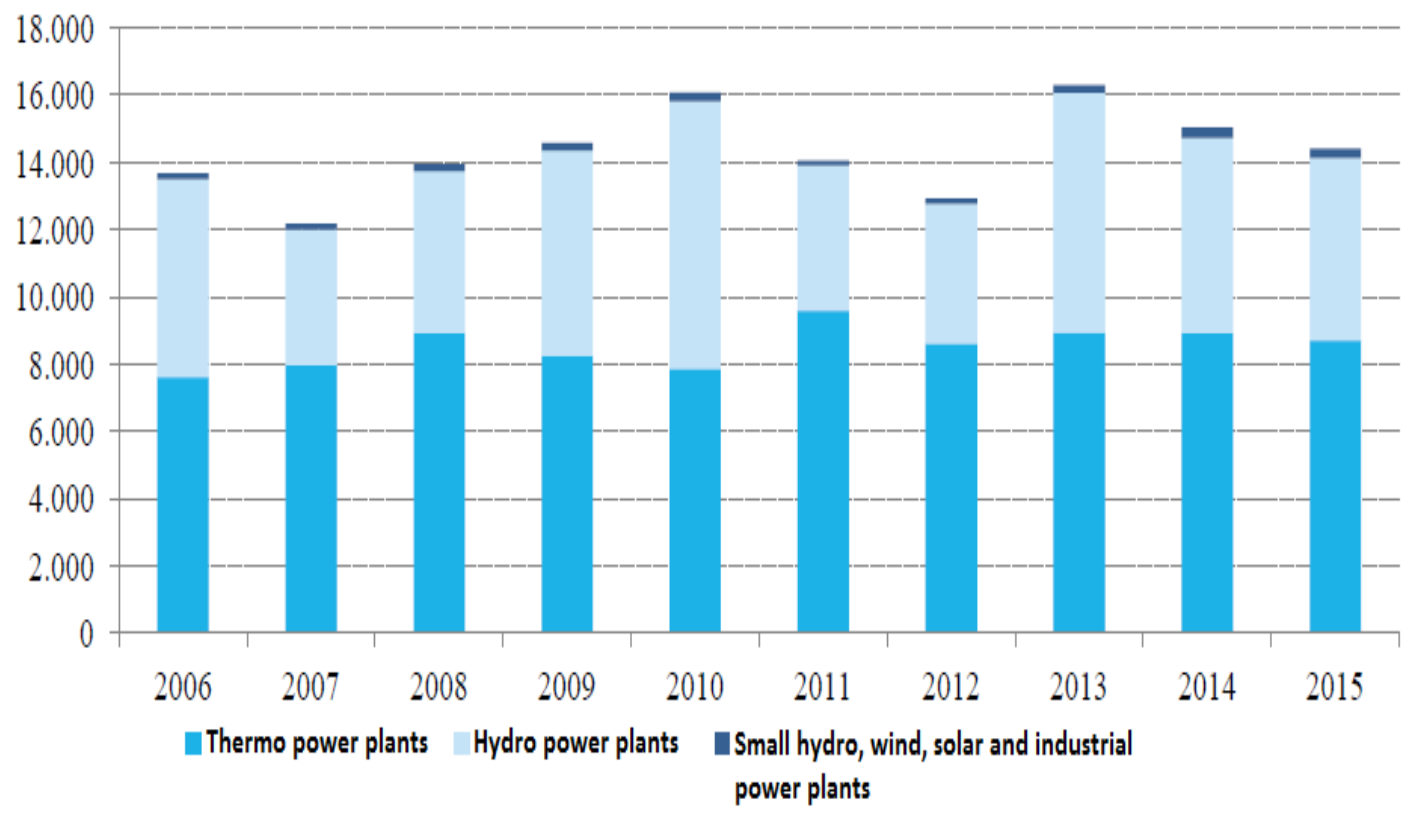

Figure 2: Structure of electricity generation in Bosnia and Herzegovina, 2006-2015 (GWh)

Source: State Regulatory Commission for Electricity in Bosnia and Herzegovina, 2015

In 2015 , total electricity generation was $14,408 \mathrm{GWh}$ and was lower by $4.1 \%$ compared to 2014 . This is the consequence of the fact that the year 2014 was characterized by favorable hydrological conditions. The electricity generation from hydropower plants in 2015 was 5,426 GWh, or 6.8\% less than in 2014. In 2015 there were moderately unfavorable hydrological conditions where the realized flows were slightly lower from multi-year averages (State Regulatory Commission for Electricity in Bosnia and Herzegovina, 2015). The electricity generation from thermopower plants was $2.3 \%$ lower in relation to 2014 and amounted to $8,712 \mathrm{GWh}$. The fall in the thermal generation of electricity in last three years (2013-2015) is largely the result of the lower coal production in mine sector and low electricity prices on the wholesale market. In relation to 2014, in 2015 the electricity generation from renewable energy sources was $6.5 \%$ lower. The small hydropower plants, solar and wind power plants produced 246.9 $\mathrm{GWh}$, while industrial power plants produced only $23.3 \mathrm{GWh}$ of electricity (State Regulatory Commission for Electricity in Bosnia and Herzegovina, 2015).

\subsection{Legal and institutional settings}

The institutional framework in Bosnia and Herzegovina is very complicated. The government structure comprises the institutions on the state level (Council of Ministers), two entity level governments (namely Bosniak-Croat Federation $(\mathrm{FBiH})$, which is also divided into ten cantons and the Serb-majority Republic of Srpska (RS)), Brčko District and municipalities. In this highly decentralized government structure, most government authority is given to two entities, whereby state level institutions of Bosnia and Herzegovina have only limited explicit powers. Energy-related issues are under the responsibility of the entities, which de facto exist independent of one another. The constitutional organization of Bosnia and Herzegovina that devolves only limited explicit powers and authority to state level institutions regarding energy matters represents one of the main barriers for creating a single internal energy market and joining the regional energy market. Other barriers that hamper the reform process include: non-existence of the Strategy for development of the electricity sector in Bosnia and Herzegovina on the state level; three energy regulators (one state and two entity regulatory commissions); the state level institutions lack the capabilities to implement growing international obligations; lack of coordinating mechanism between state-level institutions and entity level governments. On the state level, the Ministry of Foreign Trade and Economic Relations of Bosnia and Herzegovina (MoFTER) is responsible for policy formulation in the energy sector, namely for the state legislation that covers electricity transmission, system operation, and cross-border trade. The State Regulatory Commission for Electricity (DERK) established in 2004, is the regulatory authority responsible for electricity transmission, transmission-related activities and international trade of electricity.

Legal framework for electricity sector in Bosnia and Herzegovina is defined by following laws that are currently in force: 
- Law on transmission, regulator and system operator of electricity in Bosnia and Herzegovina („Official Gazette of Bosnia and Herzegovina“", 7/2002);

- Law on electricity in the Federation of Bosnia and Herzegovina („,Official Gazette of Federation of Bosnia and Herzegovina“", number 41/2002, 24/2005, 38/2005, 66/2013);

- Law on electricity in the Republic of Srpska („Official Gazette of RS“, number 66/2002, 29/2003, 86/2003, 08/2008, 34/09, 92/2009);

- Law establishing an Electricity Transmission Company in Bosnia and Herzegovina („Official Gazette of Bosnia and Herzegovina“, number 35/2004);

- Law establishing an Independent System Operator for the Transmission System in Bosnia and Herzegovina („Official Gazette of Bosnia and Herzegovina“, number 35/2004).

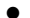

Under their own jurisdiction and divided among entity lines, legal and regulatory conditions for electricity production, distribution system operation and supply of electricity are defined by two entities in Bosnia and Herzegovina Federation of Bosnia and Herzegovina and the Republic of Srpska. Under the Law on Electricity in Federation of Bosnia and Herzegovina of 2013, the Federal Ministry of Energy, Mining and Industry and the Federal Regulatory Commission for Energy (FERK) are the key institutions responsible for the functioning of the electricity sector in Federation of Bosnia and Herzegovina. Likewise, under the Law on Electricity in the Republic of Srpska of 2008 and the Energy Law in Republika Srpska of 2009, the two key institutions responsible for legal and regulatory framework in electricity sector of Republika Srpska are the Ministry of Industry, Energy and Mining and the Regulatory Commission for Energy of Republika Srpska (RERS).

The state-level in Bosnia and Herzegovina is responsible for governing the transmission of electricity. Electricity Transmission Company in Bosnia and Herzegovina (Elektroprijenos Bosne i Hercegovine), which started operating in February 2006 is the owner of the transmission network in the country and is in charge of connection, transmission of electricity, metering, maintenance and development of the infrastructure. The state enterprise Independent System Operator of Bosnia and Herzegovina is responsible for the management and control of the transmission network, dispatching, directing, balancing, scheduling, coordinating maintenance, planning and development of the grid, allocating the cross-border interconnection capacities and development of Indicative generation plan with the company for transmission of electricity (Independent System Operator in Bosnia and Herzegovina, 2016).

\section{Bosnia and Herzegovina in the regional context}

\subsection{Development of regional electricity market}

Because of the great importance of the regional electricity market, the European Union and the countries in Southeast Europe recognized the need for harmonization of electricity sector organization in the countries of Southeast Europe with electricity sectors in the European Union. After the resynchronization of two UCTE zones in 2004 (UCTE Union for the Coordination of the Transmission of Electricity), by which the power systems of Western and Southeastern Europe were interconnected, energy event of the year 2005 was the signing of the Treaty establishing the Energy Community. The Treaty establishing the Energy Community, which was signed on 25 October 2005 between the European Union and nine Contracting Parties from Southeastern Europe in Athens, entered into force on 1 July 2006 paving the way for the creation of potentially the biggest internal electricity and gas market in the world. Extending the European Union (EU) internal energy market to its neighboring countries, the Energy Community aims to create a regulatory and market framework capable of securing reliable energy supply and attracting investments in the energy sector. The objectives of an integrated European Union (EU) internal energy market are also to enhance the security of supply, establish competitive energy markets and to improve the environmental situation. Eight Contracting Parties include Bosnia and Herzegovina, Serbia, Montenegro, FYR of Macedonia, Albania, Kosovo, Moldova and Ukraine (Energy Community Secretariat, 2015). Current member states of the Energy Community, candidates and observers are shown in Figure 3. 


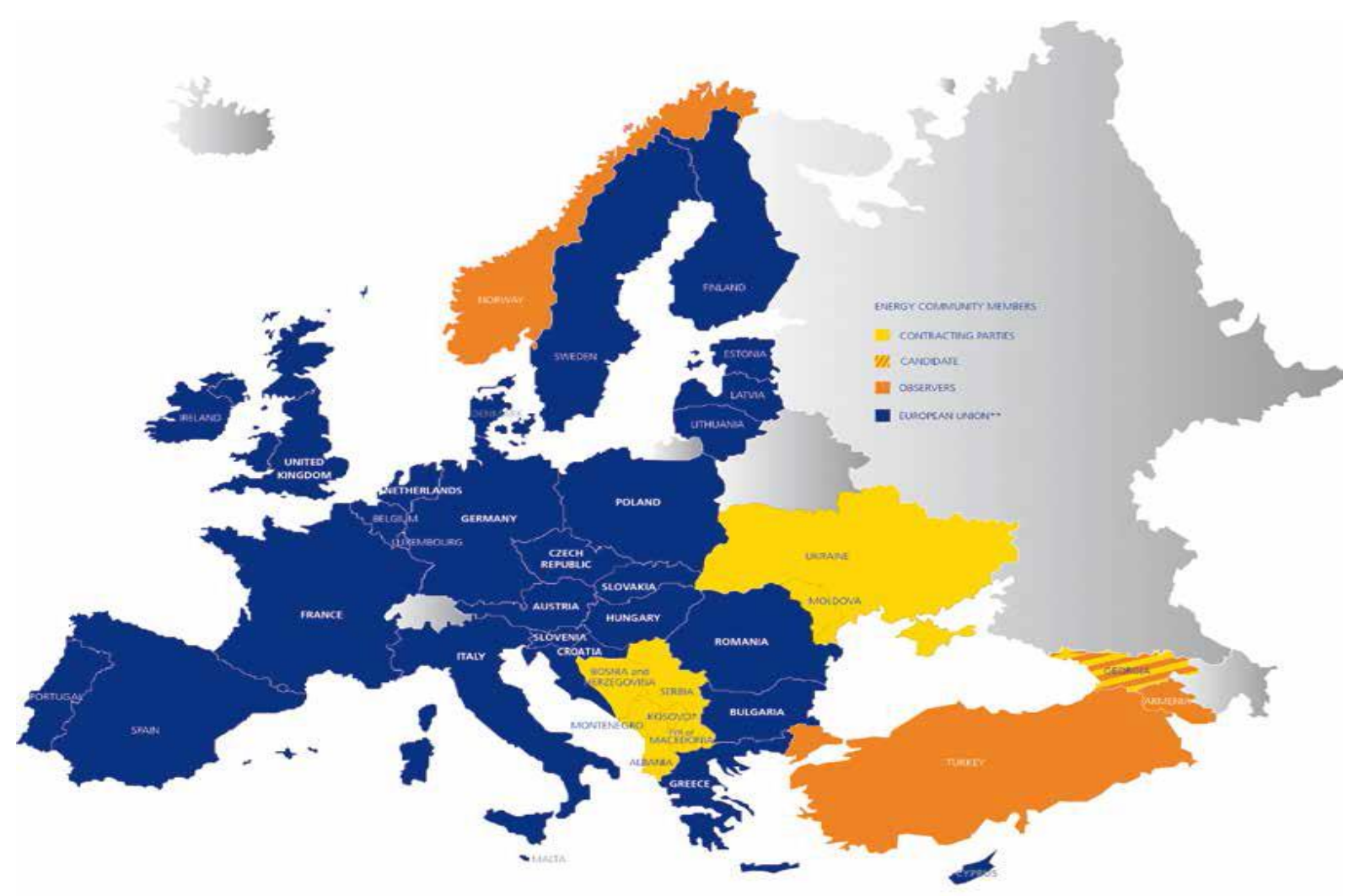

Figure 3: Member States, Candidates and Observers of the Energy Community

The European Union Member States can obtain the status of a Participant to the Treaty. The list of 19 EU Member States which obtained the status of a Participant to the Treaty include: Austria, Bulgaria, Croatia, Czech Republic, Cyprus, France, Finland, Germany, Greece, Hungary, Italy, Latvia, the Netherlands, Poland, Romania, Slovakia, Slovenia, Sweden and the United Kingdom. Observers of the Treaty are Georgia, Armenia, Turkey, and Norway, where Georgia has applied to join the Energy Community as a full member (Energy Community Secretariat, 2015).

The Energy Community acquis communautaire follows the legal framework development of the European Union and today includes its core energy legislation in areas of electricity, gas, security of supply, environment protection, competition, energy efficiency, renewable energy, oil, and statistics. Under the Treaty establishing the Energy Community European Commission has the right to propose the swift incorporation of new EU legislation to the Energy Community. The Energy Community acquis communaitaire has been adapted for several times and extended since it entered into force. The Energy Community acquis, which represents the legal framework of the European Union, is focused on the Directives and Regulations from the Third Energy Package of the European Union. They create common rules for internal electricity and natural gas markets and regulate cross-border trade. All Contracting Parties in the Energy Community are legally bound by the set of regulations that comprise the Third Energy Package of the European Union.

Two main obstacles have inhibited market liberalization process: price regulation as an instrument of social policy on the one hand and dominant role by the State in creation, operation and supervision of electricity market structures on the other. Today, in most Contracting Parties the domestic electricity system is characterized by the coexistence of an unregulated and regulated segment, which works under entirely different conditions. The single buyer models and the regulation of generation/wholesale prices represent the biggest barriers for opening and regional integration of wholesale electricity markets (Energy Community Secretariat, 2014).

\subsection{Main electricity indicators in the countries of Southeast Europe}

The energy position of the European Union was affected by various crises and disturbances on energy markets from 2008 to the middle of 2009. The most important disturbances are related to the big rise in the oil prices in July of 2008 and also to the disruption of gas deliveries by Russia through the Ukraine in January of 2009. That caused a number of difficulties for many countries in the European Union. The global financial and economic crisis, which had a great 
impact on energy markets and the energy position of the European Union was the biggest challenge. The development of electricity sector in Southeastern Europe was slowed after the collapse of the global financial sector, which resulted in economic crisis at the beginning of 2009. The fall in electricity consumption was caused by the noticeable decrease in industrial activity, especially in energy-intensive industries. The slowdown in planned investments in new electricity generation capacities was not only caused by the lack of capital and bad credit ratings in the region of Southeastern Europe but also by unfavorable investment environment. (http://www.vreme.com, 17.3.2011). During the time of recession when energy consumption decreased in all countries, energy prices remained low, especially during last two years due to the considerable decrease in oil prices. According to European Network of Transmission System Operators (ENTSO-E), countries in Southeastern Europe spent $282.25 \mathrm{TWh}$ of electricity in 2010. Therefrom, the share of thermopower plants in electricity generation was 55\%, the share of hydropower plants was $27 \%$ and the share of nuclear power was $16 \%$, while the share of renewable energy sources was $1 \%$ (http://www.vreme.com, 17.03.2011). The total electricity consumption in every country depends largely on the structure of their energy systems, availability of natural resources for primary energy production and the level of economic development. The following table shows the total electricity consumption in the countries of Southeast Europe for the period 2011-2015 (Table 1).

\begin{tabular}{|l|c|c|c|c|c|}
\hline & $\mathbf{2 0 1 1}$ & $\mathbf{2 0 1 2}$ & $\mathbf{2 0 1 3}$ & $\mathbf{2 0 1 4}$ & $\mathbf{2 0 1 5}$ \\
\hline B\&H & 12593 & 12624 & 12559 & 12210 & 12606 \\
\hline Croatia & 17474 & 17301 & 16988 & 16407 & 16984 \\
\hline Macedonia & 8948 & 8465 & 8049 & 7850 & 7403 \\
\hline Montenegro & 4183 & 3900 & 4652 & 3253 & 3418 \\
\hline Serbia & 40628 & 39667 & 39444 & 38211 & 39326 \\
\hline Bulgaria & 33452 & 32550 & 32120 & 31221 & 33244 \\
\hline Romania & 54915 & 54425 & 52303 & 52859 & 54783 \\
\hline Albania & 5657 & 5760 & 6894 & 6523 & - \\
\hline
\end{tabular}

Table 1: Total electricity consumption in the countries of Southeast Europe, period 2011-2015. (in GWh) Source: Eurostat, Balkan Energy News, 2015

Total electricity consumption in FYR of Macedonia had a negative trend for five consecutive years during the period 2011-2015. In the period 2011-2014, total electricity consumption declined in Bosnia and Herzegovina, Bulgaria, Croatia, and Serbia. The downward trend in total electricity consumption was interrupted in 2015, and total electricity consumption increased in Bosnia and Herzegovina, Bulgaria, Croatia, Romania, Serbia, and Montenegro. Countries in South East Europe with biggest total electricity consumption in 2015 were Romania (54,783 GWh), Serbia (39,326 $\mathrm{GWh}$ ) and Bulgaria $(33,244 \mathrm{GWh})$. However, the fall in regional demand for electricity is only temporary. It is expected that after the economic recovery the demand for electricity in Southeastern Europe by 2020 will rise annually in average by $2.2 \%$. Energy infrastructure in Southeast Europe (thermal power plants, hydropower plants, nuclear power plants) which was mostly built in the 1960s and 1970s, with their age, old type of technology and inadequate maintenance is another serious challenge for the countries of the region. Joining the European Union the countries in Southeast Europe will be confronted with their obligation to shut down the old, inefficient thermopower plants, which will additionally increase the need for the construction of new generation capacities. By the year of 2020, 3,200 MW generation capacities could be ,shut down“(http://www.vreme.com, 17.03.2011). Total electricity generation in the countries in Southeast Europe for the period 2011-2015 is shown in Table 2.

\begin{tabular}{|l|c|c|c|c|c|}
\hline & $\mathbf{2 0 1 1}$ & $\mathbf{2 0 1 2}$ & $\mathbf{2 0 1 3}$ & $\mathbf{2 0 1 4}$ & $\mathbf{2 0 1 5}$ \\
\hline B\&H & 14050 & 12935 & 16302 & 15030 & 14408 \\
\hline Croatia & 9961 & 9903 & 12683 & 11955 & 9611 \\
\hline Macedonia & 6327 & 5813 & 5638 & 4885 & 4927 \\
\hline Montenegro & 2632 & 2778 & 4049 & 3008 & 2827 \\
\hline Serbia & 41266 & 39900 & 43201 & 36832 & 41182 \\
\hline Bulgaria & 45143 & 41910 & 39359 & 41657 & 44519 \\
\hline Romania & 56968 & 54320 & 54485 & 60236 & 61700 \\
\hline Albania & 4159 & 4725 & 6959 & 4724 & - \\
\hline
\end{tabular}

Table 2: Total electricity generation in the countries of Southeast Europe, period 2011-2015 (in GWh) Source: Eurostat, Balkan Energy News, 2015 
Countries in South East Europe with biggest total electricity generation (thermal, hydro, nuclear, renewable) in 2015 were Romania (61,700 GWh), Bulgaria (44,519 GWh) and Serbia (41,182 GWh). For three consecutive years, in the period 2013-2015, total electricity generation declined in Bosnia and Herzegovina, Croatia, FYR of Macedonia and Montenegro. In Bosnia and Herzegovina, the trend of lower electricity generation in thermopower plants is largely the result of lower coal production as well as low electricity prices on wholesale electricity markets. Romania is the only country in South East Europe, which was able to increase their total electricity generation for four consecutive years (2012-2015), while Bulgaria increased their electricity generation in the period 2013-2015.

\subsection{Electricity trade in Southeast Europe}

The region of Southeast Europe is characterized by a diverse structure of the energy mix in total electricity generation. There is a mix of conventional thermal generation, hydro plants, nuclear power and other renewable sources. However, there is a big difference in generation structure among different countries in Southeastern Europe. Albania, which is a high degree import dependent on electricity, gets almost all of its domestic generation from hydropower plants, whereas UNMIK gets almost all of its domestic generation from thermal plants (lignite). Hydropower has almost $40 \%$ share in electricity generation in Croatia, Bosnia, and Herzegovina and Serbia. On the other hand, Bulgaria and Romania have a high share of domestic generation from nuclear power and are the only two countries with nuclear generation in South East Europe. Some of the countries in South East Europe are heavily dependent on import of electricity, namely Croatia, FYR of Macedonia, Albania and Montenegro. Only Bosnia and Herzegovina, Bulgaria and Romania are not dependent on import of electricity (Pöyry, Nord Pool Consulting AS, December 2011.).

The regional electricity generation mix emphasizes the importance of electricity trade and significant benefits could arise through improved regional trade. Hydro and thermal systems are excellent complements because hydro energy can be stored which leads to improved security in electricity supply. The following figure shows the electricity trade balance in the countries of Southeast Europe in the period 2012-2015.

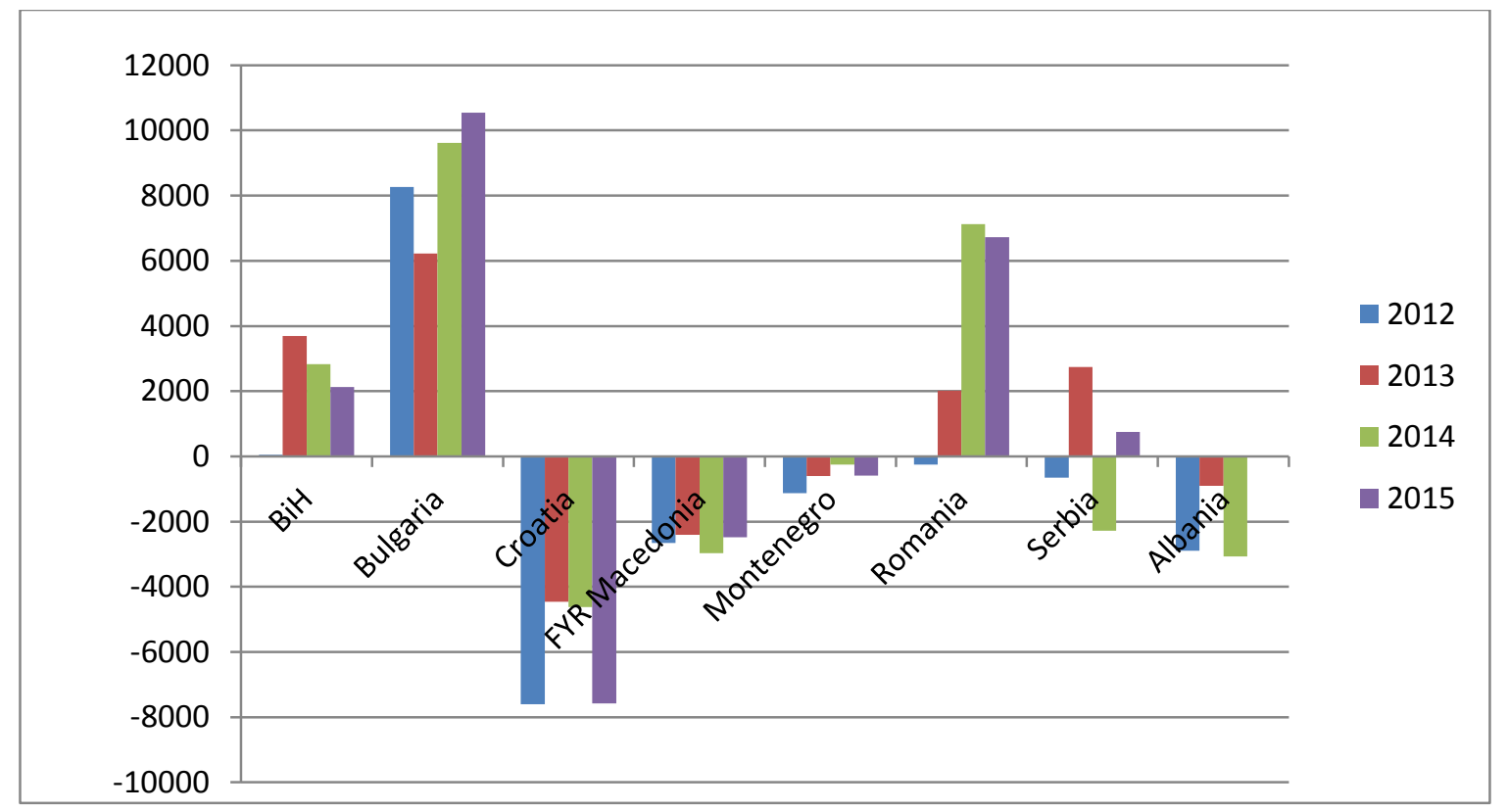

Figure 4: Electricity trade balance in the countries of Southeast Europe (in GWh), period 2012-2015 Source: Authors based on data from Balkan Energy NEWS Publication, 2015.

Note: Data not found for Albania in 2015.

The biggest net exporters of electricity in South East Europe are Bulgaria, Romania and Bosnia and Herzegovina. At the same time, Bulgaria and Bosnia and Herzegovina are the only countries in South East Europe that had a positive trading balance sheet through the period 2011-2015. Romania is usually also a net exporter of electricity, but due to unfavorable hydrological conditions, it had a negative trading balance sheet in 2012. Through the period of 2010-2012 Serbia was a net importer of electricity but this negative trend was overturned in 2013. Contrary to 2014 when Serbia was a net importer of electricity, in 2015 this country became a net exporter of electricity. On the other hand, net 
importers of electricity in South East Europe are Croatia, Albania, FYR of Macedonia and Montenegro. The most developed Croatia is the biggest net importer of electricity in South East Europe. Because of very favorable hydrological conditions in 2010, Albania with the highest share of hydro energy briefly achieved a positive electricity trade balance sheet.

\subsection{Electricity prices in Southeast Europe}

The regulation of electricity prices has a negative impact on the introduction of competition in electricity markets and is contrary to key principles of the Energy Community in South East Europe. Regulated electricity prices on the level below generation costs hamper the possibilities of current electricity supplier to perform their activities and provide services which lead to their lower profits. Also, there are neither incentives nor economic viability for new participants to enter the electricity supply market, which, together with a limited number of current suppliers, creates a barrier to the development of wholesale and retail electricity markets. Because of artificially low regulated electricity prices, the consumers have no incentives to switch their current electricity suppliers (Energy Community Secretariat, 2012).

The variations in electricity prices between the countries in South East Europe are caused by the differences in electricity generation costs and different electricity generation mix. Price differences across the region are also the result of different tax policies and overall economic policies that are more or less stimulative for new investments in electricity generation and electricity infrastructure. Well-functioning regional electricity market has a positive impact on electricity price conversion on wholesale electricity markets across the region of South East Europe. Electricity prices for households in the countries of Southeast Europe and EU-28 are shown in the following Figure.

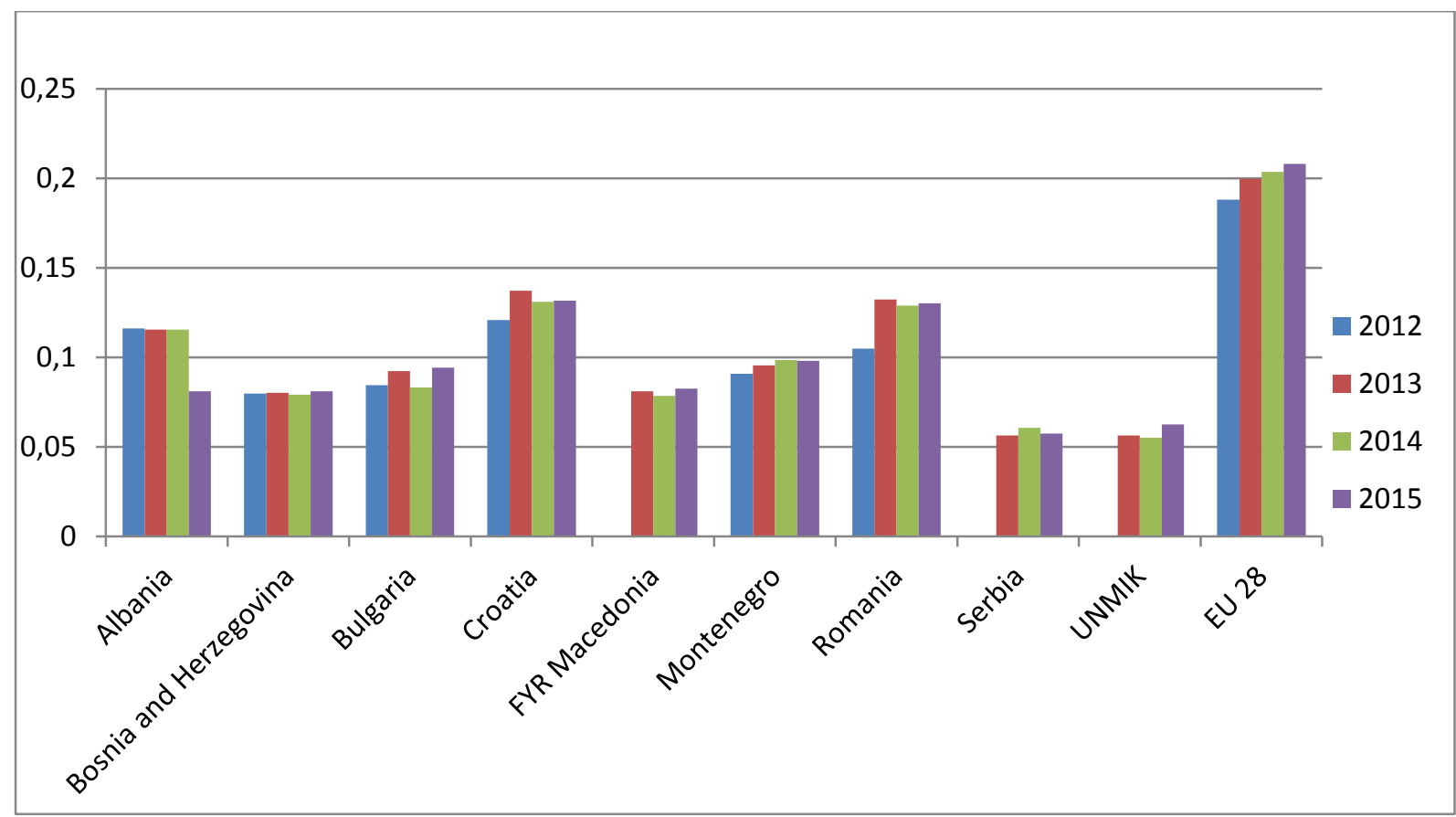

Figure 5: Electricity prices for households in the countries of Southeast Europe and EU-28, 2012-2015 (Eur/kWh)

Source: Authors based on data from Eurostat online database, 2016

Note: Data not found for FYR of Macedonia in 2012, Serbia in 2012, and UNMIK in 2012.

In the last observed year, among Southeast European countries the lowest electricity prices are paid by household endusers in Serbia, UNMIK, Albania and Bosnia and Herzegovina. In comparison to 2014, electricity prices for household end-users rose in most countries (Bosnia and Herzegovina, Croatia, Bulgaria, FYR of Macedonia, Romania, and UNMIK) and it indicates that liberalization process has not contributed to the lower prices. As it could be expected, the highest electricity prices are paid by household end-users in Croatia (0,1317 EUR/KWh in 2015) and Romania (0,1303 EUR/KWh). However, on average, electricity prices for household end-users in Southeast Europe are still significantly lower compared to electricity prices in EU-28. On the other hand, the difference between electricity prices for industrial consumers in EU-28 and Southeast European countries is much lower. These prices are shown in Figure 6 


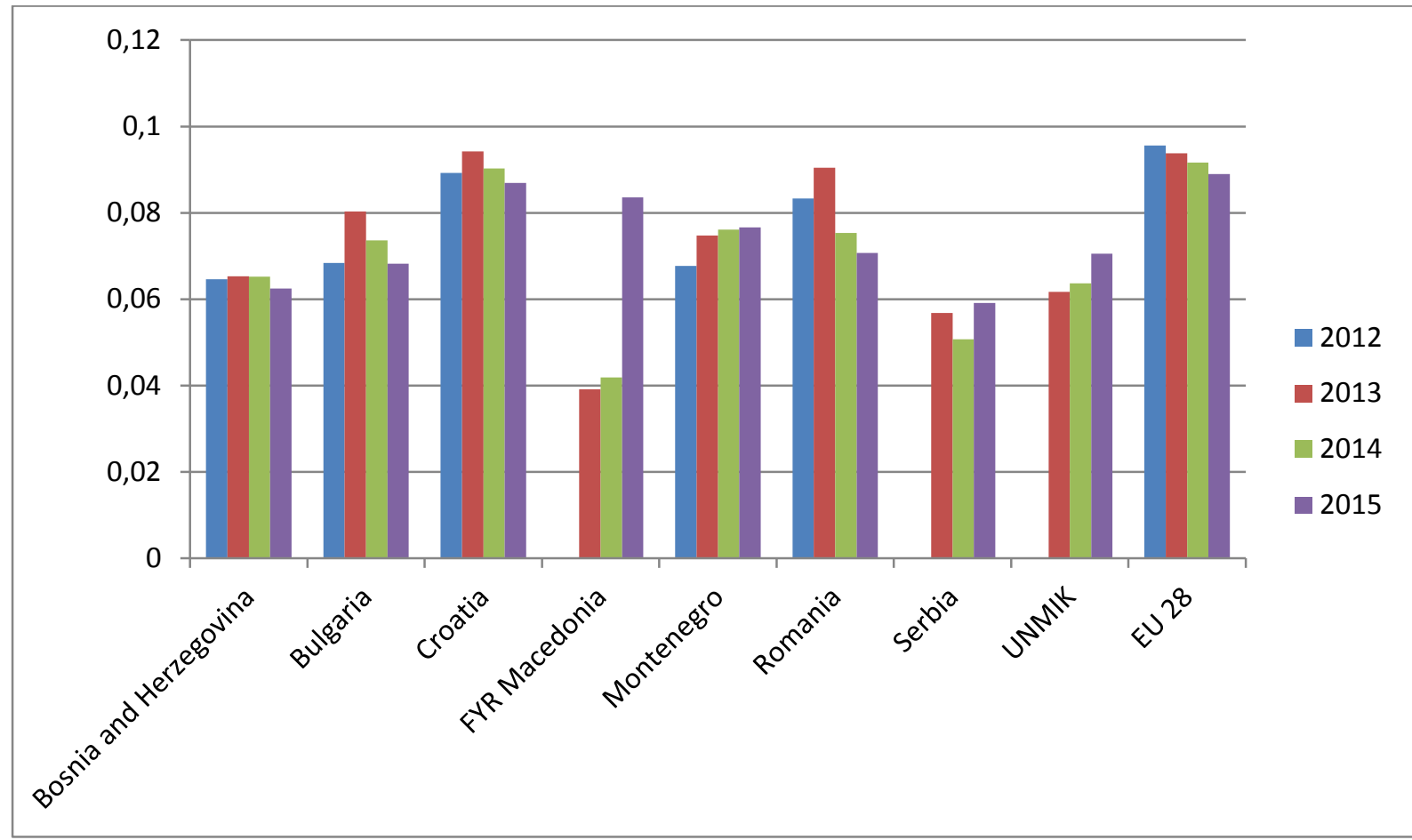

Figure 6: Electricity prices for industrial consumers in Southeast Europe and EU-28, EUR/KWh, 2012-2015

Source: Authors based on data from Eurostat online database, 2016

Note: Data not found for Albania, FYR of Macedonia in 2012, Serbia in 2012 and UNMIK in 2012.

According to data, the lowest electricity prices are paid by industrial end-users in Bosnia and Herzegovina, Serbia and Bulgaria. In comparison to 2014, in 2015 electricity prices for industrial end-users rose significantly in FYR of Macedonia. Also, electricity prices for industrial end-users rose in Montenegro, Serbia, and UNMIK. Again, the highest electricity prices are paid by industrial end-users in Croatia (0.0869 EUR/KWh in 2015), and they were almost equal with electricity prices in EU-28 (0.0890 EUR/KWh). Except for Croatia and FYR of Macedonia, electricity prices for industrial end-users in South East Europe are still significantly lower compared to electricity prices in EU-28.

\section{Current Status of Reforms and Policy Implications}

Bosnia and Herzegovina is a victim of its constitutional framework and complex political system. The complexity of the constitutional structure of Bosnia and Herzegovina, fragmented legal, administrative and political structure and the lack of political will have had a negative impact on energy sector reforms. As it has been analyzed so far, electricity sector reforms in Bosnia and Herzegovina have not been implemented, as they should according to the Third Energy Package and obligations deriving from the Energy Community membership. Despite the sanctions and infringement procedures for non-transposition of the Third Energy Package that has been adopted against Bosnia and Herzegovina, its legal and regulatory framework for the electricity market is still non-compliant with the Energy Community acquis (Energy Community Secretariat, 2016). Without cooperation at a state level, which is crucial for structural reforms and liberalization of the electricity market, the Third Energy Package cannot be transposed and implemented. However, legal framework harmonization with the Acquis communitive of the European Union is completely missing on a state level in Bosnia and Herzegovina, which hinders the required structural reforms and liberalization of the electricity market.

Although the legal compliance with the Acquis is somewhat better on entity levels, Federation of Bosnia and Herzegovina and Republic of Srpska currently do not comply with the Third Energy Package as well. According to Energy Community Secretariat (2015), the Law on Electricity in Federation of Bosnia and Herzegovina from 2013 is still far behind in compliance with the Third Energy Package. Due to complicated political structure and the current situation in Bosnia and Herzegovina, it is hard to explain why there is a lack of will for energy sector reforms in both entities although energy sector represents an important share of its GDP. 
During 2016 some new developments have occurred. In March 2016, a draft of new Law on the Regulator, Transmission, and Electricity Market in Bosnia and Herzegovina has been finalized with the main aim to transpose the Third Energy Package. At the same time, a draft of new law on Establishment of the Transmission System Operator in Bosnia and Herzegovina that will be in compliance with the Third Energy Package has been prepared (Energy Community Secretariat, 2016). The concept of eligibility is properly transposed under the Law on Electricity in Federation of Bosnia and Herzegovina of 2013 and starting from 1 January 2015 Bosnia, and Herzegovina is in full legal and regulatory compliance with Directive 2009/72/EC in terms of eligibility. In October 2014 Federal Regulatory Commission for Energy (FERK) adopted the new Rulebook for Supply of Electricity to Qualified Customers and Switching of the Supplier (Energy Community Secretariat, 2015). However, the Law on Electricity in Federation of Bosnia and Herzegovina is not in line with Article 26(2)(d) of Directive 2009/72/EC. Under Article 26(2)(d) of Directive 2009/72/EC full transposition of the obligation for legal unbundling is required by enforcing the development of compliance programs which is not the case with the Law on Electricity in Federation of Bosnia and Herzegovina (Energy Community Secretariat, 2016). In Federation of Bosnia and Herzegovina, the crucial step of restructuring has still not been implemented because distribution system operators are not unbundled from generation and electricity supply (Federal Regulatory Commission for Energy, 2014). Although the distribution system operators (EP BiH and EP HZHB) are unbundled from generation and supply only in terms of accounts, functional and legal unbundling does not exist. Accounting unbundling is also applied in Electricity Company of Republika Srpska where distribution system operators are still legally and functionally bundled with the supply in all five distribution subsidiaries.

With regard to the Third party access to transmission, it has still not been fully transposed as required by the Directive 2009/72/EC (Energy Community Secretariat, 2015). Under Article 32 of Directive 2009/72/EC, it is required to transpose the provisions related to the refusal of access to transmission network and appeal procedures. Again, it is completely missing in state-level law (Energy Community Secretariat, 2016). The establishment of a compliant market structure or access to a power exchange is not supported by the legal framework on the state level. In Bosnia and Herzegovina, there is no organized spot market or local power exchange and the electricity market operates through bilateral over the counter (OTC) agreements between the incumbent suppliers (utilities), producers and registered (licensed) traders, including exports, imports, and transits. The absence of liquid trading platforms constitutes one of the main barriers for a proper wholesale market opening. There are 22 registered suppliers in Bosnia and Herzegovina, of which seven are active on the market, 25 registered companies for electricity trade out of which 21 are licensed for cross-border trade and only two customers supplied under market conditions. Practically, there is no competition between the suppliers yet, with $93 \%$ of the electricity supplied by the four incumbent utilities in 2014 (Energy Community Secretariat, 2015).

Almost all customers in Bosnia and Herzegovina (except two large companies) are supplied by their local incumbent suppliers on divided retail electricity market along the entity and ethnic lines. Outside the local incumbent supplier borders, there is no other supply. The opening of the electricity market in Bosnia and Herzegovina is hampered by the lack of effective unbundling of the four incumbent local suppliers and their formal appointment as ,reserve suppliers" and ,suppliers of last resort" by the regulatory authorities in all jurisdictions. The entry of new electricity suppliers and effective switching is further discouraged by the lack of effective unbundling between distribution and supply within the incumbent utilities.

Regulation of electricity prices is another major problem for the functioning of the electricity market in Bosnia and Herzegovina where all eligible suppliers, including large ones and without limitations are allowed for access to regulated supply. Considering the regulation of prices in electricity generation, the situation is even worse with the customers being supplied at regulated prices (the wholesale price). The price of generation for the supply of customers is regulated under the Laws on Electricity in both entities which are directly confronted with Articles 3 and 33 of Directive 2009/72/EC and limits the switching of suppliers. Although the regulatory agencies in both entities ceased the practice of regulating retail supply prices, except for households consumers and small customers in 2016, the customers of three biggest companies that represent incumbent operators, remain supplied within the public service obligation for universal supply and supply of last resort at non-market prices. According to Energy Community Secretariat (Energy Community Secretariat, 2016), this practice is the violation of Articles 3 and 33 of Directive 2009/72/EC.

Regarding the legal framework for balancing market, it has been set up at the state level with the transposition of Article 15 of Directive 2009/72/EC. As of 1 January 2016, the new Market Rules and the consequent acts of 
Independent System Operator of Bosnia and Herzegovina (NOS BiH) for implementation of the operational environment for market-based balancing and ancillary services are in compliance with the Third Energy Package (Energy Community Secretariat, 2016).

Having in mind the previous analysis, it could be concluded that the priorities for Bosnia and Herzegovina in electricity sector reform are:

- The finalization of the ongoing process of transposition of the Third Energy Package, especially for the state-level laws;

- The unbundling of the distribution system operator as well as the consequent unbundling and certification of the transmission system operator;

- The effective deregulation of electricity prices (generation and supply), capacity building for state electricity producers to establish themselves as proactive participants in competitive electricity markets as well as the protection of poor energy customers and vulnerable consumers.;

- The development of organized platforms for day-ahead and intraday electricity trading and the designation of a national electricity market operator are crucial for the development of the electricity market. Bosnia and Herzegovina will have to remove major legal and contractual obstacles to establish an organized electricity market and market coupling;

- In addition, if economically justified, Bosnia and Herzegovina can create its own power exchange that will enable trading on the wholesale electricity market.

The implementation of so-called „soft measures“ that will reduce existing legislative and regulatory barriers and develop the institutional structures that are necessary for the functioning of the electricity market in line with the Energy Community Treaty and relevant EU acquis is crucial for the development of regional electricity market. In order to create a functional regional electricity market, which includes: (i) spot market, (ii) cross-border balancing and (iii) cross-border capacity allocation substantial efforts in terms of regulatory and institutional development are required (Energy Community Secretariat, 2016, p. 2). If the regional electricity market is to benefit both Southeast European and the EU countries, capacity building, institutional development and removal of regulatory and legal obstacles are required. Furthermore, in line with the Energy Community Treaty, new/revised legislation (primary and secondary) must be put in place.

\section{Conclusion}

The analysis shows that Bosnia and Herzegovina's electricity sector is strongly dependent on hydropower with the share of $70 \%$ in generation installed capacities, while the rest is in thermopower plants (coal-fired). However, the mix of thermal and hydro generation capacities is not equally divided between the three vertically integrated public electricity companies in three entities. Bosnia and Herzegovina has become an important regional exporter of electricity, although export is highly dependent on hydrological conditions.

Electricity sector reforms in Bosnia and Herzegovina has not been implemented as they should according to the Third Energy Package and obligations deriving from the Energy Community membership. Despite the sanctions and infringement procedures for non-transposition of the Third Energy Package that has been adopted against Bosnia and Herzegovina, its legal and regulatory framework for the electricity market is still non-compliant with the Energy Community acquis (Energy Community Secretariat, 2016). Legal framework harmonization with the Acquis communaitaire is completely missing on state level in Bosnia and Herzegovina, which hinders the required structural reforms and liberalization of the electricity market. Without cooperation at state level, which is crucial for structural reforms and liberalization of the electricity market, the Third Energy Package cannot be transposed and implemented.

Development of electricity market in Bosnia and Herzegovina has been also influenced by regional electricity market that started by European Union's incentive. The Treaty on establishing the Energy Community was signed in Athens on 25 October 2005 between the European Union and nine Contracting Parties from Southeastern Europe in Athens. It entered into force on 1 July 2006 making way for the creation of potentially massive internal electricity and gas market in the world. Extending the European Union (EU) internal energy market to its neighboring countries, the Energy Community aims to create a regulatory and market framework capable of securing reliable energy supply and attracting investments in the energy sector. All Contracting Parties from Southeast Europe started to implement reforms in the energy sector with a different pace, but Bosnia and Herzegovina has been marked as the worst performer. It is not 
wondering because Bosnia and Herzegovina is a victim of its own constitutional framework and political complexity. The complexity of the constitutional structure of Bosnia and Herzegovina, fragmented legal, administrative and political structure and the lack of political will have had a negative impact on all reforms including ones in the energy sector. The analysis showed that the legal compliance with the Acquis is somewhat better on entity levels, but they still do not comply with the Third Energy Package as well.

During 2016 some new developments have occurred. In March 2016, with the support of Energy Community Secretariat, a draft of new Law on the Regulator, Transmission, and Electricity Market that aims at transposing the Third Energy Package has been finalized. A draft of a new law on Establishment of the Transmission System Operator in Bosnia and Herzegovina in compliance with the Third Energy Package is under preparation (Energy Community Secretariat, 2016). If the regional electricity market is to benefit both Southeast European and the EU countries, capacity building, institutional development and removal of regulatory and legal obstacles are required. Furthermore, in line with the Energy Community Treaty, new/revised legislation (primary and secondary) should be put in place.

\section{Acknowledgement}

This work has been fully supported by Croatian Science Foundation under the project IP-2013-11-2203.

\section{References}

- Balkan Energy NEWS (2014) Country Reports on Energy Business, August 2014 (http://www.balkanenergy.com)

- Balkan Energy NEWS Publication (2016) Edition 257: April-1 2016, 18.04.2016

- Directive 2009/72/EC of the European Parliament and of the Council of 13 July 2009 concerning common rules for the internal market in electricity and repealing Directive 2003/54/EC, OJ L 211, 14.08.2009

- Energy Community Secretariat (2012) Annual Report on the Implementation of the Acquis under the Treaty establishing the Energy Community, 01.09.2012

- Energy Community Secretariat (2014) Annual Implementation Report, 01.08.2014

- Energy Community Secretariat (2015) Annual Implementation Report, 01.09.2015

- Energy Community Secretariat (2016) Annual Implementation Report, 01.09.2016

- Energy Community Secretariat (2016) Creating a Regional Electricity Market in the

- Western Balkans - Work Programme 11/2016, November 2016

- European Commission (2009) Report on Progress in Creating the Internal Gas and Electricity Market,

- Technical Annex to the Communication from Commission to the Council and the European Parliament,

- DG TREN Staff Working Document, SEC (2009) 287, Brussels, 11.03.2009

- Eurostat (2016) Eurostat Online Database

- Eurostat Yearbook (2011) Europe in figures, European Union

- Independent System Operator in Bosnia and Herzegovina (2016) Report on Electricity flows on

- Transmission Network in Bosnia and Herzegovina for 2015

- Pöyry, Nord Pool Consulting AS (2011) South East Europe Wholesale Market Opening, Final Report

- State Regulatory Commission for Electricity in Bosnia and Herzegovina (2015) Annual Report for 2015

- http://www.vreme.com/cms/view.php?id=981461,17.3.2011 